Article

\title{
Eco-System Services in Agrarian Value Chains: Value Detection of Bio-Diversity as Public Good Provision, Problems, and Institutional Issues
}

\author{
Ernst-August Nuppenau \\ Department of Agricultural Economics, University of Giessen, Senckenbergstraße 3, D-35390 Giessen, Germany; \\ ernst-august.nuppenau@agrar.uni-giessen.de
}

Received: 9 October 2018; Accepted: 12 December 2018; Published: 20 December 2018

check for updates

\begin{abstract}
Valuation of nature (biodiversity: BD) and in particular ecosystem services (ESS) are important prerequisites for the design of cultural landscapes as well as in agricultural policy and the generation of BD as public interest. Designs should be built on valuation and valuation is usually seen as market assignment of prices. Yet, there is a problem with market failure. BD and ESS can be characterized as public goods, both being non-rival and non-exclusive, thus demanding public provision. Largely due to public pressure, nature provision and planning has received increased attention. Especially as a means to create values i.e. in conservation projects and specifically to add value and income to farmers' value chains. Governments seek to promote BD and landscape provision by farmers, but money is scarce. Planners frequently do not know what the public wants and contingent valuation results are often regarded as insufficient because of missing vehicles of payment. There is scope for a more workable coordination process (institutional innovation) between interests in nature provision projects (being oriented at BD and corresponding ESS) and willingness to pay WTP (for foods related to nature). It is the objective to show that value chains of food products which are strongly related to nature and landscapes are a venue to go under multi-functionality for BD. The issue addressed is to offer a BD which creates WTP in value chains and serves as source of finance for BD provision. Hereby, the public is represented by an ecological management. We will primarily provide an analytical framework which merges public good provision theory with farm behavior modelling as well as draws on modeling of bargaining as solutions from social power theory. Provision is set by valuing through BD management and foods contain ESS by which the value chain improves at private good markets. Food is marketed through a special value chain and consumers help to finance public management of ESS. We distinguish the process of public preference formation from those of individual formation and can reckon a concept of social power. 1. An introduction to preference detection highlights the need for a public approach. 2. Interest group preferences are modeled. 3. A manager will be entitled to charge fees to beneficiaries and guarantee compensations. 4. Bargaining for BD indicating ESS is outlined.
\end{abstract}

Keywords: nature as public good in value chains; political economy modeling; participatory approach

\section{Introduction}

Detailed pricing of nature and design of financial institutions, which assure effective provision of eco-system services which are also preferred, are important prerequisites for the success of policies associated with multi-functionality of agriculture [1]. In decentralized economies, pricing and payment conditions are mechanisms for preference revelation. Preference formation is usually based on existing goods and services imbedded in value chains [2]. They can be understood as based on property rights and we see derived valuation techniques. However, in decentralized economies the major focus 
is on commodity exchange, realization of comparative advantage and specialization in production. Similar criteria are becoming increasingly relevant for an efficient treatment of nature as a scarce commodity, essentially in the economics of multi-functionality and ecosystem services (ESS provision). We call it nature provision [3]. In contrast to private goods, nature provision and also its evaluation are confronted with the public good problem of nature, being non-rival and non-exclusive [4], i.e., if somebody consumes a good which contains nature being an element of landscapes, in our case, nature is not declining. Also, in the case of multi-functionality of regions and landscape, for example, it is not possible to fence DB in. Importantly, specific nature or biodiversity (BD) is an outcome of the choice of landscape features and standards, which creates the need for institutions [5] and we need expenditures for landscape conservation. However, it is said that institutions create interests [6] and interests depend on valuation. A question is: will institutions appear spontaneous or is a specific design needed? Private interests seem to create markets. However, most of the preconditions for private interest in markets and value chains (normally surrounding the perfect market argument) are not satisfied in the case of BD. Making BD a marketable good is hampered by obstacles such as: heterogeneity, location specific, complex interactions of farms, mosaics in landscapes, information deficits, invisibility, etc. At the other hand value chain management [7] could be extended to multi-functionality and cooperation in a context of specific food coming from areas having high BD [8]. The issue is what multi-functionality (for ESS) is offered. Then multi-functionality and ESS should become linked to payment schemes [9].

For example if, as envisaged here, farmers shall preserve BD (economically speaking they shall provide nature) to the benefit of eco-food-users (consumers), we can refer to goods with higher value, i.e., produced with ESS. Farmers may claim that these foods reserve a mark-up which reflects values of BD. By mark-up we mean they get higher prices paid by consumers. Then BD and ESS become linked and their efforts to sustain ESS matter. Foods from areas of high multi-functionality exposed to high BD are to be double checked: paid for as public good provision and getting better price as well. The provision is a hybrid of private and public efforts, modes of payment and product design. Then payments have to guarantee that a distinct $\mathrm{BD}$ appearance, based on values which are known like market prices, is linked to farm provision and what citizens want. Preferably, a specific landscape (visible as nature elements: hedges, grassland, diversity of fields, traditional mixed farming, etc. which supports BD) should reflect preference of consumers/citizens. The idea of economists is that landscape design should be based on selective pricing [10] and farmers want compensation. Finally, BD can create a stream of benefits to eco-food-users which is welfare enhancing and 'cashed in' in a value chain. On the peculiarities about food value chains, discussing geographical origin, ecological aspects, rurality, alternatives, etc., see [11]. Pursuing the idea of economizing nature economics are eager to find ways to create interests in $\mathrm{BD}$, at least, on the side of providers; i.e., payments being financed by beneficiaries (consumers). In this regard, the paper makes a contribution to satisfy beliefs of economists that a monetarized and differentiated valuation is needed (ibid.).

For the actual provision and its modelling for planning at landscape level (below) BD should particularly coincide with supply conditions of farmers (imbedded in profits: [12]); but BD has specific costs. Importantly, some costs come with landscape orientation of BD and ESS. However, as current decline of nature in rural areas shows, the situation is farfetched from ideal. As Pretty has argued already 20 years ago, a revision of agriculture which includes subjects like sustainability, finding policies to get behavioral change of farmers, etc. is needed [13].

On the other hand, for those pursuing a non-commercial view on BD (ecological experts), it seems to be impossible to imagine BD and ESSs becoming purely commercial entities. So, there is a need for a compromise [14]. Yet business and embedding BD in value chains may be fruitful for ESS. There is a need for new concepts that bring together commercial interest and conservation. Such concepts perhaps already exist in the food business, agriculture, and multi-functionality context, however mostly at more practical levels. For example, in regions that consider them multi-functional and offer special products (wine: [8]) activists see the landscapes as assets to be worked out in marketing. 
Activists including farmers and agribusiness industries have ideas for innovation and use value chain analysis, etc. to foster special aspects of landscapes, being pleasant. These concepts and practical examples can especially be studied as innovations which emerge from interest [15]. Yet the public good problem is huge for $\mathrm{BD}$. Just to mention: free-riding on nature prevalence, claiming and non-existence for BD, information on interactions between products and nature, ESS, etc. are typical [16].

Innovations can be facilitated by the creation of public organizations that are characterized by institutional dimensions in terms of preference revelation [17] and which offer publicly accessible valuations. Institutions should identify public preferences, contribute to the design of substitutes, look at pricing of $\mathrm{BD}$, and finally ensure effective supply of $\mathrm{BD}$. Yet they also should be recognizable for customers and this is a problem in nature provision (for institutions and cooperation in nature provision see: [18]). Since information problems [19] on preferences and potentials for concrete $\mathrm{BD}$ appearance are huge, institutions may also include expert information from local ecologists. Information on potentials to meet 'demand' and 'supply', especially gained in ecologically oriented economics, can be interpreted as scarcity signals; yet for the general public the issue is to get the 'right' BD, but is it a BD which matters for all? Also, with respect to value chains for food produced with BD which is strongly related to ESS, the concern is whether actors which want the benefits from BD get the 'right product'. This has been explained above by the example of landscape appearance. Promotion with landscape appearance involves problems. To condense preferences and formulate priorities in value generation chain (VGC) and ecosystem management for BD (EMB) it is important to get a model which allows simulations. It must also guarantee involvement of participants and institutions. Vice versa we have a problem of private and public provision being joint [2]. It is the overall aim of the paper to provide a model which enables simulations of $\mathrm{BD}$ on the basis of value chain improvements and generation of finance to attract farmers in landscape-oriented nature provision.

For BD evaluation we use a concept of extended organization which is constituted of willing producers (receiving compensation payments), a public manager (setting rules) and willing consumers (contributing financially to BD). We will show how a rigorous application of a political economy model comprised of consumers which are identifying themselves with the multifunctional agriculture (buying BD products) will help us understand preference formation in VGC for EMB. It is the prime objective of the paper to provide a theoretical background for derivation of public preferences on the basis of EMB. The presented approach adopts the political economy framework of Rausser and Zusman (1992) [20] to exemplify EMB as public good provision and management. In this regard, terms like political economy and institutions are specified in a context of political bargaining theory. It distinguishes between the process of preference formation, based on individual values (as WTP minus royalties linked to product prices) and the process of pubic value generation, based on political power (as a necessary ingredient to get the product perforated, i.e., the BD wished). Then we move to the farm level and look at the willingness to accept nature elements at farm level in exchange for compensation payments (as WTA). The process shall generate a social objective function in a region that benefits from an improved BD. It is further presumed that the process can alter public (social) preferences in the interest of the more empowered individuals, since we work with political economy modelling.

At a more applied level, it is the objective of the article to show how public management can contribute to establishing financial contributions of citizens. Here citizens are consumers of special goods in the value chain throughout which nature provision is realized. A willingness to pay is institutionalized through companies gaining from improved nature in a landscape. We show how to simulate nature provision by farmers which includes willingness to contribute (accept) a certain biodiversity which is associated with multi-functionality of agriculture. Specifically, the suggested analysis shall be applicable to value chains of such products which are pronouncedly linked to multifunctional agriculture. The products are part of a design issue in landscape economics, for example vineyards e, hey-milk meadows, herbal resorts, mushroom rich forests, etc. We analyze a case in which consumers have a special interest in the provision of a specific BD based on ESS which is subject to landscape elements and ESS is based on functioning ES. Again, ESSs are not 
free and indirectly offered by farmers. Yet, it is presumed consumers and farmers prefer eco-foods and are willing to accept institutions such as regulations, payments, etc., which result in eco-foods. Food should be rendered to be produced in a more ecologically sound manner. However, specifying financial contributions in value chains (which are beyond referenced prices of ordinary food) as well as paying a mark-up to companies (as regulations envisaged) are not easy to find. Perhaps, they generate finance, but is it also optimal and fits to individual participation? The finance goes to public management and this management has interest on the one side. On the other side, public management then sends money to farmers which are rewarded for BD provision on the same interest in a specific $B D$.

The paper is organized in five sections: (1) An introduction to the concept of public preference building in BD will stress the need for public good approaches [21] in nature provision and the need for monetary evaluation. (2) Preferences of eco-food-users are modeled in a VGC mode to generate money for public management. (3) A manager of the public good BD will be entitled to charge contributions (royalties) and (4) the bargaining solution will be presented. Finally, the paper summarizes findings and discusses prospects for further research.

\section{Concept and Research Outline}

We presume some consumers, who are willing to pay (WTP) for ESS [22]. At a high level of awareness, they may think to cooperate in nature conservation with farmers by buying products which are more ecologically sound. However, though they may be concerned with a special nature, a question is do they get it? The further question is: will they get a nature/landscape, they like, based on selection of products? Selection is discriminatory, and it depends on knowledge about BD. On the payment side cooperation is on the basis of financial contributions for characteristics of nature (i.e., for instance for a certain BD). On the product side, it is assumed that consumer/citizens expect a specific preferred nature and WTP is further discriminatory in the sense that for landscape design it matters. About expectation on landscape design it shall result in what we may call an ecological main structure EMS [3] which is characterizing a landscape through nature elements. Further, as any EMS has a landscape design component which is linking agriculture to nature appearance, the consumers' willingness to pay becomes associated with multi-functionality; which in a wider sense means amenities, local foods, etc.

In a first phase we assume farmers have full rights to land use in a first phase. i.e., the EMS is only provided by willing farmer. In a second phase rights are traded against compensation. However, this creates a problem because payments on landscape and farmers cannot be exclusive to single farms; rather we have to address groups of farmers and the landscape is public. Then the danger is that landscape becomes specifically in terms of landscape elements chosen by farmers and not conducive for an overall design idea. This idea has to be promoted by management of all farmers. It is further presumed that the EMS structure is to the benefit of all in cooperation and cooperation between farmers is needed, yet we see landscape and nature provision (BD) as public good in character [23]. In its very nature landscape and ES are [16] indivisible. It is this feature which means it needs coordination and planning for design by the management, but also on behalf of consumer. The tricky thing is: does the management represent the will of consumers/citizens?

Concerning the structure/design of regulations, rights, and commitment, we assume that those who are eco-food-users have interest in nature preservation. Therefore, we can say they are joining in cooperation and, by definition, are citizens who prefer specific nature are committed to buy products at higher prices. The higher price is expressed as gains in value chains. This can be expressed by products, but also by suppliers of the products. Suppliers can be food processors or various intermediaries in which even farmers can have a stake. That is on the side of food as private goods.

Looking at the natural background in production, prominently, we do not see an easy definition of the public good 'nature' representing ESS; rather the definition needs a specification for its management. This management should evenly be interested in provision. As a non-private intermediary, it has to 
find out what is meant by nature. We see BD as variables which can be specified. Then food products offered to the consumers should be related to BD. There shall be a consensus in the cooperation towards nature provision and value generation. At least in EMS and landscape design, for example expressed as hedges, buffer strips, etc., there is need for cooperation. However, there is also scope to make it visible to consumers who visit an area and buy special foods on the one hand. On the other hand, there is a need for 'design' of this nature on basis of ecological knowledge. The specification of nature must be done actively reaching a consensus, i.e., it has to be asked: what is specific in nature to make customers willing to pay and what is an ecological necessity? Then the specific appearance or "design of nature" (BD as modifiable public good) is up to cooperation and individual preferences are to be respected for finance. Otherwise, there is not enough finance to pay for compensation to farmers. Note the same idea prevails in reference to 'multi-functionality' which offers a venue for suppliers to get better price and upgrade value chains. For example, linked to already existing special landscapes, Nazzaro et al. (2016) [24] state that multi-functionality offers changes in food provision for high quality and priced products. A question is: do areas with higher multi-functionality gain in sales automatically or is it passive vs. active? In our query, the emphasis is on active provision. As we will show the vehicle for payment shall be a mark-up on food price which we can be a royalty. i.e., some foods which are strongly associated with EMS will have a higher WTP in the food chain, specifically containing more ESS, and this is taxed.

We see payments expressed as individual financial contributions, but they shall also serve farmers collectively by financing nature provision. However, we additionally see the problem that ESS provision encompasses a supply problem and the supply is not individual. It needs finance and planning as well as charging royalties on food must be linked to the concrete, planned existence of a preferred $\mathrm{BD}$. This might not be the case all the time, especially if the public is already challenged to finance nature as a public good [25]. In the corresponding debate we depart and want the public to be supported by a private sector of food suppliers who gain from nature (BD).

Our view is that if such finance is not really made available and an intermediary is missing, the system of supply and demand (even for public goods) will be sustained. However, here we think there is a need for an intermediary for nature management which we call EMB: nature management for biodiversity. From the perspective of resource economists, who are making recommendations to nature managers, we have to contemplate the size and composition of nature. The issue is that the final 'product' (BD) has to fit supply and demand. Demand as built by preference (and costs as payments) for consumers is not self-evident. Like in product design and innovation philosophy the provider has to meet consumer preferences. A formal approach must inform us about revealed willingness to contribute to an ecological main structure (EMS being the ESS source) by ECO-food-users and we need a simulation of how it translates into ESS.

We envisage cooperation for nature management with a local company which is specialized in selling regional products, farmers and nature management. The products are associated with biodiversity and ESS. Actually, it is a set of goods and services which the company offers to consumers encompassing ESS and BD. Perhaps, in a special case, the company can even take over management of the public good itself or affiliate with nature management. This can be a particular case, for example, in hunting [26].

In general, having involved several actors, a certain percentage of the price (higher than normal) paid by consumers is used to subsidize farmers for provision of ESS and the rest is used for revenue purpose as part of an extended value added in the chain. In a regional cooperation the farmers eventually also gain by an increase in product price. However, the company which has control over the value chain, should specifically direct the provision of biodiversity offering gains from improved value chain management. Biodiversity is associated with ESS which makes it complex. Farmers themselves are not directly interested in ESS, because ESSs are public goods and free-rider is best without regulation and coordination. Additionally, the company has costs for marketing and promotion depending on the complexity of the BD sponsored. For example, we do not think only about 
prestigious animals which make a region exceptional (cranes, beavers, etc.) or offer scope for example as hunting and as private good; rather several, ecologically needed species as a set of synergizing ESS shall be promoted simultaneously and it is the task of BD management to set rule and offer payments to farmers. Farmers are providing landscape elements and, indirectly, habitats.

In our case of linking nature and food chain, participating companies, their cooperation with nature supply management and then farmers shall assure refinement of BD. Feeling well served on the side of consumers shall result in higher payments for food and a type of long-term commitment which may even lead to informal and formal contracts. The promotion of BD is dome by companies because interest is created. To strengthen the financial base for provision of $\mathrm{BD}$ and to determine size and composition, the 'good' itself has to be specified in a process of concerted action and beneficiaries (consumers with a reasonable WTP) will commit to payments $[27,28]$. We see companies in value chain management as taking over jobs for raising money, but also to jointly specify products with the eco-management of a region. In this regard, value chain management and the corresponding logic of a concerted action are seen as promoters, sponsors, and active parts [29]. Specific questions like scaling-up from supplier to landscapes have to be addressed in particular. In that frame a wider view on management than pure value chain management for individual food branches or companies is guested. A question is: how can the link between food represented in value chains and land use types be established [30]? We think it is nature management that can give an answer by doing nature valuation and management as shown below.

The task of nature management for ESS provision is more complex than food provision in a simple market. There is an immediate need for reloading of ESS contained in goods, determination of royalties, and size of payments to encourage providers. We also need a structure of payments for ESS [31]. This complicates the situation. The negotiation on simultaneous finance and nature appearance becomes a problem in terms of cooperation for what? Rejection of regulations on land use at the side of farmers, which are not of interested, is a problem to be anticipated. Yes, there might be nature management already, but how does it decide explicitly on specific habitat outlines when it comes to wished BD appearance and directing finance by intention of companies. For instance, are we looking at species combination, such as shrubs, trees, butterflies, etc., which promote pure nature or nature appealing to citizens? Even as the size of an ecological main structure EMS matters, nature must become a quantifiable figure representing collective preferences in cooperation, and the finances have to be found.

The job and innovation can be described as companies' and management tasks in designing products on behalf of eco-food-users which are containing ESS and which are embedded in a landscape. Instead of just thinking to offer BD in nature reserves, which serve the general public, we have to venture in landscape design and land sparing vs. sharing in an issue [32]. At the end, design ought to be negotiated with ecologists based on finance. Then there is again the idea of getting finance through products specifically associated with multi-functionality (for example in the case of wine in Italy, there are such ideas in practice, see: [24]). Then companies hopefully pay royalties to be taken by nature management. Royalties serve as endogenously decided sets of charges on value added or prices. Finally, they serve to finance nature. Companies start caring about attribution of preferences to foods sold at different stages of nature appearance (as a public good).

The concept enables us to research and detect marginal utility of BD if we think about simulations. The core product in simulation is BD being landscape oriented and specific. We are of the opinion that a manager for $\mathrm{BD}$ on behalf of companies will only be able to reveal users' preferences after research has gone through the process of simulating appearance of $\mathrm{BD}$. Then negotiating royalties and offering payments to farmers is the next step. In particular, derived from 'use' and 'non-use' values of nature we receive values and preference lists for specific BD (supporting ESS). On the ground of scarcity and opportunity costs, users of a landscape, which is characterized in habitat outline (biotopes), may have different choices on the combination of $\mathrm{BD}$ (nature). This has to be made apparent in regards to qualifying landscapes as more or less conducive for nature provision as well as improving value 
chains. In economic terms: especially, if there shall be an appropriate pricing of $\mathrm{BD}$, marginal providers and users have to be identified. It has to be determined which farmer can contribute additionally (with which money) to marginal ESS element provision. At the user level, the concerted group of interested actors in the value chain needs to know how to get new customers. For instance, in economic terms: management has to find the marginal dollar from a user, who is willing to pay and buys a specific piece of land. This land for example is then dedicated to owl preservation. Knowing that this is a demanded conservation measure, customers make the food from this land higher priced.

From the ecological perspective, management has to decide which amount of money is necessary to preserve a minimal population of owls, i.e., to prevent owls from going extinct. Selling food with an owl logo (branding) can then be a solution. Apparently, this presents a direct link, but in the end only at the surface for consumers. While money provides incentives, ultimately it is the overall planning which enables the realization of landscapes conducive for the survival of owls. It has to be noticed that nature is not confined to single species, say owls and the product with an owl logo sells best. Many landscape elements and nature provision as a whole, ESS, are involved in the owls' well-being. However, for a generalization, announcing prices for different nature elements and looking for price formation as a process of linking supply and demand, which gives simulations, should make preferences transparent. Below we argue for a cooperative management. It shall be gained in cooperative decision making of companies and farmers which are guided by nature management.

Nevertheless, admittedly, our disciplinary focus is still more or less that of neo-classical economics (for a critic see [33]). Our request for behavioral change towards true cooperative behavior is limited. It assumes that value chain analysis VCA [34] is a necessary tool for participation, interest generation, willingness to finance BD, etc. In also implicitly assumes that VCA makes organizations functional, i.e., with minimal government intervention. Perhaps there is a problem with sufficiency [9] and more governance is needed, but this is beyond the paper.

However, differentiated pricing of BD (actually equating marginal WTP and WTA) should enable decision makers to get signals for improving local decision making. This issue must be seen against choice alternatives for landscape development. To enable selection between different nature conservation projects, a full set of prices on specified ESS elements should be accomplished. We take the position that biodiversity BD as species appearance is important for judging priorities and a vehicle for coordination and payment is also given. Especially, WTP can provide information on what to sponsor. Decision makers have to build social preferences and announce corresponding prices. Our contribution is developing a mathematical model which supports the job of valuation on the basis of public management. To appreciate increases in welfare of eco-food users due to sounder nature appearance, prices for BD have to be published. Pricing and in particular price ratios enable recognition of substitution options in projects for cost minimal management.

In this regard, it is the objective of the paper to show how simulations can be built on modeling for cost minimization in landscape provision of $\mathrm{BD}$, based on a pricing which additionally involves public management for product definition. In general, pricing (as part of extended VGC) is needed for retrieving specific WTP and enabling better design and management of BD in value chains. Since not all BD conservation activities can be pursued under scarcity of land and finance (competition of projects), a socially-accepted priority list will help practical policy to make decisions. About regulations to be specified, we look at royalties and compensation payments. Finally, ex-post monitoring of projects requires pricing to support measures of actual appearance and successes in nature provision projects.

\section{Individual Preferences and Preference Aggregation in Public Decision Making}

\subsection{Eco-Food-User Preferences for Nature}

In order to detect financial potentials in value chains which will enable public management to offer compensation payments to farmers for the provision of EMS, we start the analysis with an inclusion of preference for species " $\mathrm{s}$ " (a vector) in utility. As later shown, in financing BD provision, 
consumers shall contribute to BD provision specifically through public management. This management is financially supported by money raised through royalties to be generated from consumer WTP as charges on products for BD. Yet, it is part of a broader modelling of WTP. For instance, wildlife found in a cultural landscape [3] can represent the vectors " $s$ ". This set of species comes to the recognition of consumers as biodiversity BD. Firstly, it is our identification of nature. Secondly, it is later linked to farm practices as part of landscape design. Thirdly, nature provision in cultural landscapes is associated with these practices [35]. The full understanding of the price transmission is then put in the hands of the nature management.

For modelling of the demand side of "s" (here in a combination of consumer, companies and public needs) a landscape-nature-prevalence approach is envisaged. It is at the level of EMB and says that the " $\mathrm{s}$ " (prevalence of detectable appearance of nature at species level) is traced back to efforts (below). Then modeling of eco-food-consumers (users)' preferences starts with an indirect utility function and the assumption that each individual (user, alternatively group) has a constrained indirect utility function including nature appearance. The information is condensed in "s", because it can be payment oriented and the further data on the connectivity of efforts, ecology and planning would be too complex. However, the preference is for a specific BD "s" (a species vector to be generated by management). Indeed, can work with constrained utility [22]. Additionally, we have to include a payment mechanism as mentioned. The payment " $z$ " is added to the price in Equation (1) and the quality " $\mathrm{Q}$ " of the product is a function of " $\mathrm{s}$ ". This indirect utility function depicts a preference ordering of usual foods and ecologically produced foods (containing "s"). A user cannot alter BD of "s" directly, but (s)he evaluates $\mathrm{Q}$ and s jointly. i.e., (s)he cannot change BD by purchasing it directly; rather it is embedded in specific food. The utility function recognizes payments of an eco-food-user. This user will make decisions on products and regionalism of $\mathrm{BD}$ as well as pay for costs of the EMB indirectly. There is an agreement on the level " $\mathrm{z}$ " of the mark-up of food consumption which is constrained as food with BD: "s"; i.e., products which are translatable into a special species appearance element (the process of building preferences is not investigated). The appearance is sufficient and is consistently translated into landscape appearance which is the envisioned job conducted by EMB for multi-functionality. In a coordinated system of transactions along institutional arrangements, it is the task of the managers in cooperation to set royalties to individuals. They are part of a simulation which is the mathematical task of modelling (below) and finally they should become endorsed in the concept of public BD provision. Public provision depends on participation and we show the benefits approving the win-win situations. As we may introduce companies selling products and charging mark-ups " $\mathrm{z}$ ", the consumer willingness is a matter of mark-up minus additional costs, for example of separate handling, marketing measures, etc. The utility function is

$$
V^{i}=V^{i}\left(p^{o}, p^{r}+z, y, Q\right)=V^{i}\left(p^{o}, p^{r}, y-p^{r^{\prime}} z^{\prime} q^{r}, E, s\right)=V^{i}\left(p^{o}, p^{r}, y-p^{r^{\prime}} z^{\prime} A s-c^{i} s, s\right)
$$

with

$\mathrm{V}=$ indirect utility function

$\mathrm{p}^{\mathrm{o}}=$ vector of prices for ordinary goods $(1 \ldots \mathrm{k})$

$\mathrm{p}^{\mathrm{r}}=$ vector of prices for regional goods $(\mathrm{k} \ldots \mathrm{m})$ associated with multi-functionality

$\mathbf{s}=$ vector of public species BD characteristics, for instance, species appearance as representing ESS

$q=$ vector of $m$ products containing different ESS and the link is given by a transformation matrix $E$

$\mathrm{z}=$ mark-up, royalty by company $\mathrm{z}=\mathrm{p}(1+\%)^{\prime} \mathrm{Q}^{*} 1 / \mathrm{n}$, i.e., the company offers monetary contribution to public good provision

$\mathbf{c}^{\mathrm{i}}=$ constant monetary contribution to public good, i.e., vector of prices for s (s translates into $\mathrm{q}$ )

$\mathrm{A}=$ matrix which translates eco-system services into food characteristics

' = is a horizontal vector; it reads, for example in case of revenue, as: price multiplied by quantity: $\Sigma_{\mathrm{i}}$ $p_{i} \cdot q_{i}=p^{\prime} \cdot q$ 
The individual welfare function (1) contains the information of an eco-food user's preference order over all commodities. It is a revelation built on willingness to pay for "s" via commodities, i.e., we use a species vector to correlate preferences and later activities to find the coordination (market) equilibrium. From the viewpoint of ecologists, it comprises various ESSs expressed as BD.

To simplify one can think of " $\mathrm{s}$ " as a vector of species which is reflecting a "good nature" seen by consumers. The author is fully aware, that ecologists will see consumers having preference for nature critically; but they have them for "regional" products containing "s". Notice the royalty " $\mathrm{z}$ " serves financing of nature in terms of creation of public good " $\mathrm{s}$ ". In this case, on behalf of "consumers", we can argue that an indirect access to preference ordering and money works. For example, the consumer may be indifferent between 30 oak trees as compared to 150 birches. Alternatively, if provided by ecologists, the vector of "s" can also be a biodiversity index. For instance, the presentation of biodiversity by a Shannon Weaver Index $H_{s}=\sum s_{i} \log s_{i}$; Schaefer, 1992. This can be written in matrix algebra as $\mathrm{H}_{\mathrm{s}}=\mathrm{s}^{\prime} \log \mathrm{s}$. The preference itself is then based on an index and not an individual weighting. Regarding the mechanism of payment, there are two elements so far. A royalty (a fee enforced by the local management being institutionalized) which is charged to regional product purchases and a lump sum payment (as for example regional tax). Royalty " $\mathrm{z}$ ", being seemingly proportional to the purchase of commodity, and a fixed payment per species "a", being a flat rate, are to be specified by the management (as part of local governance). There is a right that the management can alter finance for the "public" in value chain achievement. The higher price $\mathrm{p}^{\mathrm{r}}$ is announced by the food industry and as revelation it serves to calculate z. For the public management, the peculiarity is that not "markets" decide on value, rather management has to calculate a price for the public good which it does by budgeting (below). Pricing is actively done but exogenous to consumers. We will then, in (2), use a quadratic approximation, working simply with variations to specify the function and can specify utility on the basis of statistical measures for BD "s".

In terms of WTP, which is the welfare indicator, an eco-food-user will pay unless his position between utility improvement and payment is maximized. This also reflects willingness to receive a better status of nature "s" (improvement) that is publicly done. Yet "s" is led by policy, it is dignified to income (willing to concede) and $z^{\prime} \times q$ facilitates advances $z^{\prime}{ }^{\prime} A$ 's. For convenience, let us assume the constrained indirect utility function of individual " $\mathrm{i}$ " is given by a quadratic function.

$$
\mathrm{V}^{\mathrm{i}}=\chi_{2,0}{ }^{\mathrm{i}^{\prime}}\left[y-\mathrm{p}^{\mathrm{r}} \mathbf{z}^{\mathrm{r}^{\prime}} \mathrm{As}-\mathrm{c}^{\mathrm{i}^{\prime}} \mathrm{s}\right]+\chi_{2,1^{\mathrm{i}^{\prime}}} \mathrm{s}-0.5\left[\mathrm{p}, \mathrm{y}-\mathrm{p}^{\mathrm{r}} \mathbf{z}^{\mathrm{r}^{\prime}} \mathrm{As}-\mathrm{c}^{\mathrm{i}^{\prime}} \mathrm{s}\right]^{\prime} \Gamma_{2}\left[\mathrm{p}, \mathrm{y}-\mathrm{p}^{\mathrm{r}} \mathbf{z}^{\mathrm{r}^{\prime}} \mathrm{As}-\mathrm{c}^{\mathrm{i}^{\prime}} \mathrm{s}\right]+0.5 \mathrm{~s}^{\prime} \Gamma_{1}{ }^{\mathrm{i}} \mathrm{s}+[\mathrm{p}]^{\prime} \Gamma^{\mathrm{i}}{ }_{3}{ }^{\prime} s
$$

This functional expression of preference has the advantage that it can integrate a vector of the public good " $s$ " (the BD) directly. The vector representation $s^{\prime}=\left[s_{1}, s_{2}, \ldots, s_{n}\right]$ recursively has the advantage, that it explicitly distinguishes the various aspects of ESS in provision (see below).

The idea is that WTP shall be shared with the eco-management. The inclusion of $\mathrm{z}$ as mark-up and payment for amenities (below as price deduction) not only serves the purpose to get finance while there is an interest, rather it also directs EMB. We see companies in a position to present the interest of the citizen/consumers. A simple version is one product per company. Then, in contracting and purchasing of food which contains BD, EMB interest moves in the same direction as the company's; just presenting interest of consumers for BD. As a further simplification, a company shall finance royalties for contained species " $\mathrm{s}$ " per se; i.e., individual consumers reveal WTP indirectly.

\subsection{Getting Preferences for Nature of Public Planner}

The next and decisive step is to translate the consumer WTP which is expressed as marginal utility in " $\mathrm{z}$ " into public preference modeling (as reference to political economy modeling). The public preference shall serve a specification of the objective function of a social planner. Here we see need for institutional change [36], though we are modest again and want to still put the frame in ordinary economics. We addressed how money (value) is generated already. However, the above function can serve as benchmark for optimal provision of an EMS due to WTP, but it is not leading a market. 
The problem we have to struggle with is that " $\mathrm{s}$ " is landscape oriented and like for private individual goods, it cannot be separated in small bits and pieces.

Let us presume that companies can represent consumers' WTPs rightly; but how are they aggregated? For the appearance of the wished BD it is important to know that problems exist with respect to BD as a public good [31]. A major issue is that single species cannot be raised (provided in economic terms) in separate production processes. Rather, conversely, species are part of an ecosystem (ES) with many forward and backward linkages. In fact, we have to reduce the complexity of ES and this will be done at farm level (below) by assuming that farmers can contribute to the establishing of an ES. Farmers shall support ES by landscape elements [37] and it is the task of public management to design a landscape as a single unit which has all the necessary ingredients to come up with an inseparable nature. This nature by its "very nature" is holistic and by that feature it is non-rival; meaning that the consumption of individual consumers as we discussed in terms of products produced in a multifunctional landscape will not have an impact on the consumption of others. Furthermore, we assume that nature is also non-exclusive. This holds unless a company owns the nature. Rather we see nature, ecosystems and landscape as something which is characterized by open access [38]. In our opinion there is nobody putting a fence around a landscape?

Then, ideally, vertical aggregation is an expression for non-exclusiveness and non-rivalness of nature. Figure 1 is a stylized version of an evaluation of public good provision on the basis of consumer preferences and corresponding market simulation. Again, since it is the aim of the paper to show that integration of value chain management for ecologically sound products into nature provision is possible, we refer to vertical integration as a tool to get the pubic objective function. Vertical aggregation would ideally guarantee Pareto optimality [39]. In our framework of nature appearance and derivation of aggregated WTP, the aggregated demand function of nature " $\mathrm{s}$ " in the Figure 1 serves as a benchmark to judge efficient provision by the public good manager. However, the approach is ideal so far and later we will come to a more practical and reality-prone version in which the manager is modelled along interest missing here.

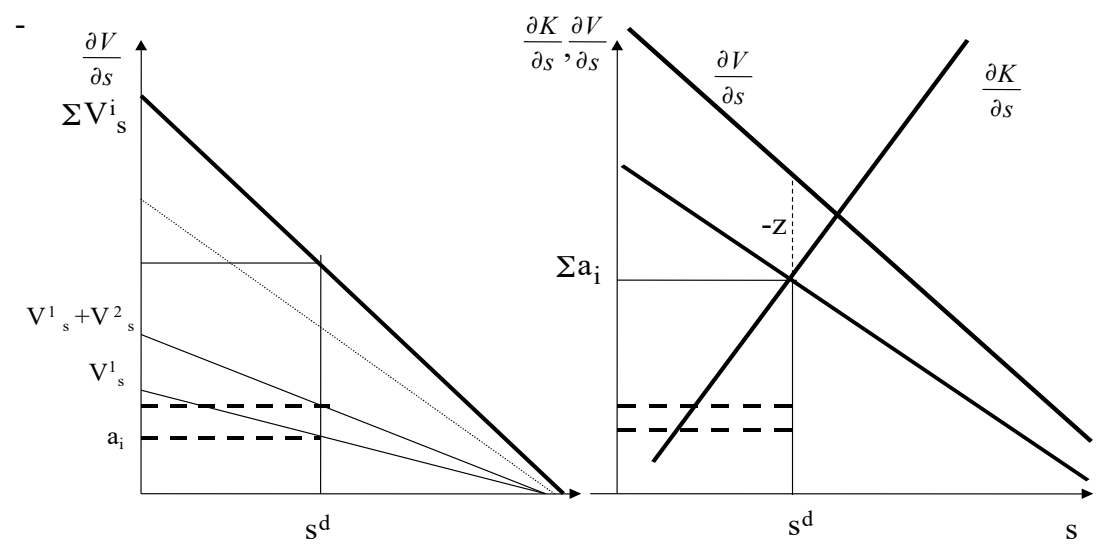

Figure 1. Aggregation of public preferences and social allocation of public goods. Source: Modified according to Bowen, 1969.

Still vertical integration provides the economic rationale for aggregation of preferences with multiple eco-food-users. Notice " $\mathrm{s}$ " is fixed, but can be simulated. Indeed, a type of simulation of a missing market is the basis for theoretical consideration on value generation from $\mathrm{BD}$; the provision itself shall be as shown later in the hand of management [40]. Vertical integration also serves as a basis for mechanisms designed to translate preferences via royalties into payments [21]. Choice variables for payment are " $\mathrm{z}$ " and " $\mathrm{a}$ ". The aggregation of preferences for regional BD expressed as $\mathrm{s}$ is collectively determined. It can be done by simulation, though we also need management. Technically speaking, the management unit vertically summarizes preferences and announces mark-ups and royalties. It serves as a joint public agency. Preference building becomes institutionalized and partly 
personalized for companies. Marginal preferences for public good " $\mathrm{s}$ ", which is represented by V'( $\ldots, \mathrm{s})$, are summarized vertically as depicted in Figure 1. In the figure we see vertical integration on the left and the potential equilibrium on the right side. Inclusion of " $\mathrm{z}$ " as royalty shifts the demand inside, which has to be anticipated in the new equilibrium.

As a suggestion for innovation in simulation of $\mathrm{BD}$ as public good, the presented approach differs from previous research which had a theoretical emphasis on policy-based voting [28]. Soon we will show how it can enter into a partial manager's objective who has interest. Through the introduction of the institution "management" on behalf of consumers, prices are determined by budget constraints (see below). The betterment is that there is authority given to management. Nevertheless, seemingly being voluntary in participation, such a management-oriented approach contains an element of coercion in terms of fixing royalties and partiality and in terms of distributing benefits [40]. For a discussion of organizational structure in management as well as setting of regulations as part of institutions, we again refer to [38]. Furthermore, governance ought to be modeled as based on existing interest; but we need simulations. We have to introduce $\mathrm{z}$ as a part of interest (price mark-up) which can be interest of managers. It follows or takes control over landscapes. That may reflect true life. More strategy is beyond; perhaps a more general investigation is needed. Here we only/exclusively model the formation process of interest.

\subsection{Farmers' Willingness to Provide Nature}

The next part is to clarify the provision of BD (in a sense of nature production) at farm level. In a way there is a layout of multi-functionality MF to be accomplished. The previous section on eco-food-user preference and simulation of vertical integration has highlighted the need for and mode of simultaneous consideration of eco-food-user and management issues as part of the demand; now the so far excluded supply will be addressed. Again, the emphasis is on creating interest for cooperation which will serve the institutional amendment to clarify on regulations for pricing as well as help the group to get financial transfers established by simulations. We need to specify a club type of the supply of BD perhaps called multi-functionality in the wording of the farm lobby. Instantly, farmers should provide nature on basis of paid activities and they will lobby for good payments. In the given frame specification of provision of nature must be a supply vector of species: " $\mathrm{s}$ ". It must be embedded in farm behavior. To simplify the analysis, firstly, we treat farmers as if they indirectly provide " $\mathrm{s}$ " based on ecological main structure EMS being conducive for MF and then EMB. Then the manager of the public good as actor in EMB negotiates with land users (or their lobby, below next section on bargaining in political economy).

Farms receive money raised by management as compensation for provision of BD (for the technology approach see [4]). Practically, payments to farms are collected from a given number of eco-food-user-companies that have agreed upon shares to contribute to total payment (above) and budgets match (above). For the reason of compact presentation, we assume again a vector (s, BD species) and matrix $\left(\Xi^{\mathrm{f}}{ }_{\mathrm{i}}\right)$. Cost is expressed as a quadratic-constrained-cost-function $C(\mathrm{~s}, \mathrm{r})$. Grouped and individual provide " $\mathrm{s}$ " (above species) on basis of incurring costs. Yet the frame fits with an optimization as maximizing the difference between revenues minus costs.

$$
\begin{aligned}
& \pi^{\mathrm{f}}=\text { Revenue }- \text { Cost }=\mathrm{p} \mathrm{s}-\mathrm{C}\left(\mathrm{s}, \mathrm{r}, \mathrm{q}^{\mathrm{r}}\right) \\
& \pi^{\mathrm{f}}=\ldots+\left[\sum \mathrm{p}^{r} z^{r^{\prime}} A+\mathrm{c}^{\mathrm{m}^{\prime}}\right] \mathbf{s}-\phi^{\mathrm{f}}{ }_{01}^{\prime} \mathbf{s} \phi^{\mathrm{f}}{ }_{02}{ }^{\prime} \mathrm{r}-\phi_{0}^{\mathrm{f}}{ }^{\prime} \mathrm{q}^{\mathrm{r}}-0.5 \mathbf{s}^{\prime} \Xi^{\mathrm{f}}{ }_{1}^{\prime} \mathbf{s}+\mathbf{s}^{\prime} \Xi^{\mathrm{f}} \mathrm{r}+0.5 \mathrm{q}^{\mathrm{r}} \Xi^{\mathrm{f}}{ }_{1}^{\prime} \mathrm{q}^{\mathrm{r}}+\mathbf{s}^{\prime} \Xi^{\mathrm{f}}{ }_{2} \mathrm{q}^{\mathrm{r}}
\end{aligned}
$$

where now and additionally:

$\pi=$ profit by farmers

$\mathrm{a}^{\mathrm{m}}=$ subsidy by manager

$\sum \mathrm{p}^{r} z^{r^{\prime}} A+\mathrm{c}^{\mathrm{m}^{\prime}}=\mathrm{a}^{\mathrm{m}}=$ overall sum of contributions for $\mathrm{s}$ (equals price paid to farmers).

Maybe farms will also receive a better price for regional products, though they are restricted in supply of conventional products. This is beyond the current simulation because it is thought that 
the prices are exogenously set. Farms will simply be awarded compensation according to vector appearance "s". Provision is voluntary "s". Actually, it would mean that participation constraints and not only incentives are to be checked. We drop that and assume that it is imbedded. Compensation " $c$ " is due to negotiations (below) or simulation. Payments modify financial budgets; i.e., announcement and commitment of nature provision should fit to eco-food-users' preferences. For a spatial outline see [37]. Furthermore, note that there is only one "s"; the public good, at regional level. " $\mathrm{s}$ " and " $\sum \mathrm{c}$ " are determined by management. Simplified to a single nature element, say oaks, it could be found that 50 oak trees are optimal. Theoretically, marginal revenue minus marginal cost determines willingness to supply (i.e., specific composition for " $\mathrm{s}$ " costs) by farmers at individual level. Here $\mathrm{s}$ is horizontal: $\mathrm{s}^{\mathrm{s}}=\sum \mathrm{s}^{\mathrm{i}}$. The manager suggests a linear combination of incentives $\sum \mathrm{p}^{r} z^{r^{\prime}} A+\mathrm{c}^{\mathrm{m}^{\prime}}$ and " $\mathrm{s}$ " is delivered (4)

$$
\mathbf{s}=\Xi^{\mathrm{f}}{ }_{1}^{-1}\left[\sum \mathrm{p}^{r} z^{r^{\prime}} A+\mathrm{c}^{\mathrm{m}^{\prime}}-\phi_{0}^{\mathrm{f}}-\Xi_{2}^{\mathrm{f}} \mathrm{r}\right]
$$

For simplification, the more complex, though condensable formulation is $\sum \mathrm{p}^{r} z^{r^{\prime}} A+\mathrm{c}^{\mathrm{m}^{\prime}}=\mathbf{a}^{\mathrm{m}}$ and

$$
\mathbf{s}=\Xi_{1}^{\mathrm{f}}{ }^{-1}\left[\mathbf{a}^{\mathbf{m}}-\phi_{0}^{\mathrm{f}}-\Xi_{2}^{\mathrm{f}} \mathbf{r}\right]
$$

In terms of the job for public management, formulation of incentives in Equation (4a) gives supply of nature " $\mathrm{s}$ " by farmers (incentive). That is, supply is dependent on compensation " $\sum \mathrm{p}^{r} z^{r^{\prime}} A$ $+\mathrm{c}^{\mathrm{m}^{\prime} \prime \prime}$. Also for the value chain generation of the money, transferred to farmers, and budgeting of the management, financial analysis must include as many willing farmers as possible. Consumer campaigns and design aspects emerge which is considered a consortium job. The Formula (4b) is used for policy description by management which promises desired BD (publically) and information of the public on how farmers are benefiting. Ideally, simulations make decisions transparent. EMB management then shall meet demand (preferences of eco-food-users) and negotiate supply with farmers.

\section{Political Bargaining as Solution}

In the last sections our analysis dealt with an ideal aggregation of preferences, value chain gains and provision of ESS expressed as a vector " $\mathrm{s}$ " for BD. The problem is that, by any means, it cannot come in existence by a perfect mechanism because of the public good character of $\mathrm{BD}$ in landscapes as well as the fact that multi-functionality is collective and singular. In this section, we outline a political economy bargaining model that enables an effective modelling of payment and provision by a committed public management. A political bargaining model is suggested, because it offers both investigation in modes of preference summation and payment to farmers on the one side as well as it investigates a bias formed by political power on the other side. ESSs have to be jointly managed by cooperation between companies that are working with value chain gains and which have the opportunity to raise funds through better selling of regional foods, and management channeling money to interest in specific BD of farmers.

We refer to political bargaining as outlined by Rausser et al. (2012) [41], though there are different analyses [36], they come to the same conclusion: power is involved. Political economy bargaining as a process appeals to a structure of bilateral negotiations. Negotiations are between a syndicate management gaining from BD and eco-food-users represented by companies. The management of the syndicate is entitled to raise money in the value chain and uses money for payments to farms having interest. The management is equipped with some power, simultaneously guaranteeing payment by eco-food-users and nature provision by farmers at cooperative level. This feature implies multiple bargaining [42]. Note that a multiple bargaining model, like real politics, enables one to depict the heterogeneity of interests in public good provision, asymmetric powers, and enforcement problems. In comparison to a benevolent dictator model, it is more realistic.

Because management as mediator has to consider interests and political power of individuals or groups, final decision will not only rely on overall welfare, but also on power and support which is 
based on interest and alternatives. The formulation of interest functions can be done in modern game theoretical fashion. This has the advantage of already recognizing bargaining positions of participants in a game. We outline that below. Especially, strategic behavioral functions can be modeled. Therefore, response functions to conflicts in interest are feasible.

\subsection{Value Chain and Welfare Analysis in Terms of Consumer Surplus}

Describing "interest functions" in the value chain as promotion for multi-functionality and ESS, we start with the above eco-food-users enjoying benefits from buying preferred (above) food produced with BD. There is a bargaining on the total surcharge " $\mathrm{a}$ " and the elements $\mathrm{z}$ and $\mathrm{c}$ are individually addressed components on what is requested and feasible. $\mathrm{z}$ has the function of being a public incentive. From the calculation of budgets, the manager additionally provides the subsidy $\mathrm{a}^{\mathrm{m}}$ to farmers. Subsides are financed and collected compulsorily. This is feasible because the selling company charges a mark-up, but its interest is to deliver as little money as possible. Still, it implies that Equation (4a) can be used to specify individual interest for negotiating. The function must be inserted. It includes supply " $\mathrm{s}$ " as incentive and costs of lobbying " $\mathrm{c}$ ". Costs of lobbying have to be deducted, reducing the welfare.

$$
\begin{aligned}
& \left.\mathrm{I}^{\mathrm{i}}=\chi_{2,0}{ }^{\mathrm{i}}\left[\mathrm{y}-\mathrm{a}^{\mathrm{i}^{\prime}}[\mathrm{I}+\mathrm{E}] \Xi^{\mathrm{f}}{ }_{1}^{-1}\left[\sum \mathrm{a}^{\mathrm{j}}+\mathrm{a}^{\mathrm{i}^{\prime}}+\mathrm{a}^{\mathrm{m}}-\phi_{0}^{\mathrm{f}}-\Xi^{\mathrm{f}}{ }_{1} \mathrm{r}\right]\right]-0.5 \chi_{2,2^{\mathrm{i}}}{ }^{\mathrm{i}} \mathrm{y}^{\mathrm{i}}-\mathrm{a}^{\mathrm{i}^{\prime}} \mathrm{s}_{0}\right]\left[\mathrm{y}-\mathrm{a}^{\mathrm{i}^{\prime}} \mathrm{s}_{0}\right]+\left[\chi_{0}{ }^{\mathrm{i}^{\prime}}+\mathrm{x}^{\mathrm{i}^{\prime}} \Gamma_{3}{ }^{\mathrm{i}^{\mathrm{i}^{\prime}}}+\right. \\
& 0.5\left[\sum \mathrm{a}^{\mathrm{j}^{\prime}}+\mathrm{a}^{\mathrm{m}^{\prime}}-\phi_{0}^{\mathrm{f}}-\Xi_{2}^{\mathrm{f}} \mathrm{r}^{\prime}\right]^{\mathrm{f}} \Xi_{1}^{-1} \Gamma_{1},{ }^{\mathrm{i}} \mathrm{f}^{\mathrm{f}-1}\left[\sum \mathrm{a}^{\mathrm{j}}+\mathrm{a}^{\mathrm{m}}-\phi_{0}^{\mathrm{f}}-\Xi_{1}^{\mathrm{f}} \mathrm{r}\right]-\mathrm{c}^{\mathrm{i}}
\end{aligned}
$$

Eco-food-companies will negotiate on $\mathbf{a}^{\mathbf{i}}$. Decisions will be made upon knowledge and guarantee on eco-food-partners' $\sum \mathrm{a}^{\mathrm{j}}$, upon subsidy $\mathrm{a}^{\mathrm{m}}$ by management, mark-up and upon guarantee by nature provision $\mathbf{s}$. Reducing coefficients, one receives a structurally simple version

$$
\begin{aligned}
& \mathrm{I}^{\mathrm{i}}=\mathrm{x}^{\mathrm{i}^{\prime}} \Phi^{\mathrm{i}, \mathrm{o}^{\prime}}\left[\mathbf{a}^{\mathrm{i}}+\sum \mathrm{a}^{\mathrm{j}}+\mathrm{z}^{\mathrm{k}}+\mathrm{a}^{\mathrm{m}}\right]+0.5\left[\mathbf{a}^{\mathrm{i}^{\prime}}+\sum \mathrm{a}^{\mathrm{j}^{\prime}}+\mathrm{z}^{\mathrm{k}}+\mathrm{a}^{\mathrm{m}^{\prime}}\right] \Phi^{\mathrm{i}, 1}\left[\mathbf{a}^{\mathrm{i}}+\sum \mathrm{a}^{\mathrm{j}}+\mathrm{a}^{\mathrm{m}}+\mathrm{z}^{\mathrm{k}}\right]+\mathbf{a}^{\mathrm{i}^{\prime}} \Phi^{\mathrm{i}, 2^{\prime}}\left[\sum \mathrm{a}^{\mathrm{j}}+\mathrm{a}^{\mathrm{m}}-\mathrm{z}^{\mathrm{k}}\right] \\
& +0.5 \mathbf{a}^{\mathrm{i}} \Phi^{\mathrm{i}, 3^{\prime}} \mathbf{a}^{\mathrm{i}}-\mathrm{c}^{\mathrm{i}}
\end{aligned}
$$

In this presentation, the interest function of any negotiating member in the cooperation appreciates her/his net benefit. Formally it is calculating gains minus payments. Contributions are made while food products are bought at reference prices $\mathrm{p}^{\mathrm{r}}$ (incl. regional WTP). However, nature appearance " $\mathrm{s}$ " is derived from total finance $\mathrm{a}^{\mathrm{i}^{\prime}} \mathbf{s}$. $\mathrm{a}^{\mathrm{i}^{\prime}} \mathbf{s}$ is a sort of sum of individual WTP of companies which are representing the individual beneficiaries (food; for example, from mushrooms, hay-milk, herbs, etc.). Since the supply is anticipated the management can negotiate contributions by eco-food-companies. Vice versa, companies will check actual prevalence and size of $\mathrm{s}$ which determines the will for additional payment. The interest in BD is depending on the size of s and on the assertion of the groups' (other) contribution to $a^{\mathrm{j}} \mathbf{s}$. It also reckons the mark-up and the potential subsidy of executive $\mathrm{a}^{\mathrm{m}}$ that reveals extra interests of the group. The negotiating member of cooperation acknowledges social power of the management which is created by enforcing finance contributions as part of contracts between him and other groups.

\subsection{Farmers}

From the farmers' point of view of, they have to make a judgement on the sum of money (compensation) which can be received from consumers' WTP for eco-foods " $\sum \mathbf{a}^{\mathrm{i}}$ ". They check desired composition of nature "s". Again, in this paper we take a narrow view and the analysis might be broader [9]. In the frame of political economy payment offered at community level there is an issue with bargaining. The focus is on management's task (known to farmers). We presume that management has interest and the budget. Actually, management can simulate horizontal and vertical contributions for money and species. Recalculating the sum of willingness to pay for the public good at price " $\sum \mathrm{a}^{\mathrm{i}}$ " and given "s" (provisionally on knowledge of "demand") results in the supply of multi-functionality in the eyes of farmers. Multi-functionality becomes part of the farmers' specification of interest function and it enters behavioral options towards nature. 
Simulating the interaction in a technical fashion, the manager could maximize the sum of consumer and producer benefits and adds gains from revenue minus cost of his management

$$
\begin{aligned}
& \mathrm{W}=\sum \mathrm{V}^{\mathrm{i}}+\pi^{\mathrm{f}}+\left[\mathrm{u}-\mathrm{a}^{\mathrm{m}}\right] \mathrm{s}+\left[\mathbf{z}^{\prime}-\mathrm{c}\right]^{\cdot} \mathrm{E}^{\prime} \mathrm{s}
\end{aligned}
$$

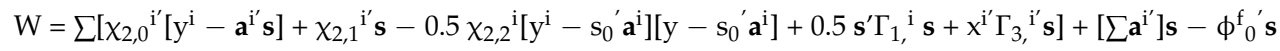

$$
\begin{aligned}
& -0.5 \mathbf{s}^{\prime} \Xi^{\mathrm{f}}{ }_{1}^{\prime} \mathbf{s}+\mathbf{s}^{\prime} \Xi^{\mathrm{f}}{ }_{2} \mathrm{r}+\left[\mathrm{u}-\mathrm{a}^{\mathrm{m}}\right] \mathrm{s}+\left[\mathbf{z}^{\prime}-\mathrm{c}\right]^{\cdot} \mathrm{E}^{\prime} \mathrm{s}
\end{aligned}
$$

This allows us (management) to derive the "balancing of supply and demand" by taking the first derivatives to " $\mathrm{s}$ " and setting (7a) to zero for optimality. Therefore, the farmers know what is requested from them. By that, we receive

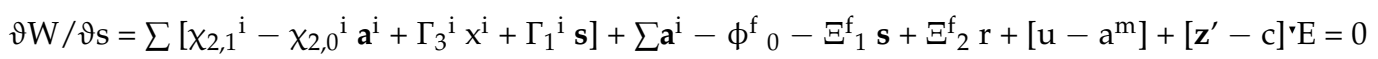

as the criteria for balancing supply and demand of s. Apparently, the first part includes consumer preferences that can be interpreted as 'demand'. Presuming that $\chi_{2,0}{ }^{i}$ is similar to all citizens, $\chi_{2,0}{ }^{i}=$ $\chi_{2,0}$, i.e., marginal utility towards income is equal (see standard argument for the use of markets as a tool for aggregation of preferences), the demand side can be specified as

$$
\mathbf{s}=\left[\sum \Gamma_{1}{ }^{\mathrm{i}}\right]^{-1}\left[-\sum \chi_{2,1}+\chi_{2,0} \sum \mathbf{a}^{\mathrm{i}}+\left[\mathrm{u}-\mathrm{a}^{\mathrm{m}}\right]+\left[\mathbf{z}^{\prime}-\mathrm{c}\right]^{*} \mathrm{E}-\sum \Gamma_{3}{ }^{\mathrm{i}} \mathrm{x}^{\mathrm{i}}\right]
$$

(Note the constant is expressed further as $\left.a^{m^{*}}=\left[u-a^{m}\right]+\left[z^{\prime}-c\right]^{*} E-\sum \Gamma_{3}{ }^{i} x^{i}\right]$; the focus is on $\sum \mathbf{a}^{\mathbf{i}}$.)

Then from the framer's side supply comes individual but it is embedded in the management goals of total " $\mathrm{s}$ ". Inserting (8) into profit function (3) of farms and deducting the efforts for negotiations " $\mathrm{c}$ ", an interest function can be established due to the bargaining position in nature provision by farmers. In game theory, given the constraint of manager's capability to balance supply and demand (i.e., bundling of interests of eco-food-users), this procedure implies an optimization of the interest function of individual farms. In total, the accumulation of interest functions of farmers depicts the sector's bargaining positions. In receiving payments on the basis of contributions by eco-food $\sum \mathrm{a}^{\mathrm{i}}$ and manager $\mathrm{s}^{\mathrm{m}}$ interest, farmers maximize with hope of highest charges to eco-foods

$$
\begin{aligned}
\mathrm{I}^{\mathrm{f}}= & {\left[\sum \mathrm{a}^{\mathrm{i}^{\prime}}+\mathrm{a}^{\mathrm{m}^{\prime}}\right]\left[\sum \Gamma_{1}{ }^{\mathrm{i}}\right]^{-1}\left[\sum \chi^{\mathrm{i}}{ }_{0}+\chi_{2,0}{ }^{\mathrm{i}} \sum \mathrm{a}^{\mathrm{i}}+\sum \Gamma_{3}{ }^{\mathrm{i}} \mathrm{x}^{\mathrm{i}}+\mathrm{a}^{\mathrm{m}^{*}}\right]-\left[\phi^{\mathrm{f}}{ }_{0}{ }^{\prime}-0.5\left[\sum \Gamma_{1}{ }_{1}^{\mathrm{i}}\right]^{-1^{\prime}}\left[\sum \chi^{\mathrm{i}}{ }_{0}+\right.\right.} \\
& \left.\left.\sum \chi_{2,0}{ }^{\mathrm{i}} \mathrm{a}^{\mathrm{i}}+\sum \Gamma_{3}{ }^{\mathrm{i}} \mathrm{x}^{\mathrm{i}}+\mathrm{a}^{\mathrm{m}^{*}}\right]^{\prime}+\mathrm{r}^{\prime} \Xi_{2}{ }^{\mathrm{f}}\right]\left[\sum \Gamma_{1}{ }^{\mathrm{i}}\right]^{-1}\left[\sum \chi^{\mathrm{i}}{ }_{0}+\sum \chi_{2,0}{ }^{\mathrm{i}} \mathrm{a}^{\mathrm{i}}+\sum \Gamma_{3}{ }^{\mathrm{i}} \mathrm{x}^{\mathrm{i}}+\mathrm{a}^{\mathrm{m}^{*}}\right]-\mathrm{c}^{\mathrm{f}}
\end{aligned}
$$

Farmers will negotiate on the contributions (comparable to prices for private goods). The detailed outline is captured by $\sum \mathrm{a}^{\mathrm{m}}=\sum \mathrm{p}^{r} z^{r^{\prime}} A+\sum \mathrm{c}^{\mathrm{m}^{\prime}}$ which means that $z^{r}$ are derived as well as $\mathrm{c}^{\mathrm{m}}$. Accepting the bargaining process and condensing coefficients to unified coefficients in Equation (9b), farmers can calculate their bargaining position on basis of $\mathrm{I}^{\mathrm{f}}$ which is

$$
\begin{aligned}
\mathrm{I}^{\mathrm{f}}= & \mathrm{x}^{\mathrm{f}^{\prime}} \Phi^{\mathrm{f}, \mathrm{o}^{\prime}}\left[\sum \mathrm{j}\left[\sum \mathrm{p}^{r} z, j^{r^{\prime}} A+\sum \mathrm{c}^{\mathrm{m}, \mathrm{j}}\right]+\left[1 / \mathrm{n} \sum \mathrm{p}^{r} z, j^{r^{\prime}} A+\sum \mathrm{c}^{\mathrm{m}, \mathrm{i}}\right]^{\prime}\right]+\left[\sum \mathrm{j}\left[\sum \mathrm{p}^{r} z, j^{r^{\prime}} A+\sum \mathrm{c}^{\mathrm{m}, \mathrm{j}}\right]+\right. \\
& {\left.\left[1 / \mathrm{n} \sum \mathrm{p}^{r} z, j^{r^{\prime}} A+\sum \mathrm{c}^{\mathrm{m}, \mathrm{i}}\right]^{\prime}\right]^{\prime} \Phi^{\mathrm{f}, 1}\left[\sum \mathrm{j}\left[\sum \mathrm{p}^{r} z, j^{r^{\prime}} A+\sum \mathrm{c}^{\mathrm{m}, \mathrm{j}}\right]+\left[1 / \mathrm{n} \sum \mathrm{p}^{r} z, j^{r^{\prime}} A+\sum \mathrm{c}^{\mathrm{m}, \mathrm{i}}\right]^{\prime}\right] }
\end{aligned}
$$

This function is a dual function on price incentives and it comprises the profits achievable in complying with nature provision. Farmers will negotiate on maximizing profits, demanding high contribution $\sum \mathrm{a}^{\mathrm{i}}$. Their interest function depicts 'political market structure' perceptions.

\subsection{Management, Interest, Role of Companies, and Task of Public Management Unit}

Now we need management interest and must seek provision of specific nature $\mathrm{s}^{\mathrm{m}}$ on the basis of interest. Since we will have interaction of eco-food consumers and companies on the demand side and farmers and eco-management on the supply side, specific interests on $\mathrm{s}^{\mathrm{m}}$ may prevail (for instance ecologist will prefer wild instead of cultural landscapes). It is formed by the constraints 
the management faces [37]. Yet it means that management which has the enforcement right and power for BD enrollment has to look at money. We will argue that an eco-management must be given the power to achieve a compromise on provision of " $\mathrm{s}$ " with farmers based on compensation payment. Then the management is equipped with money from consumers via companies being interested in multi-functionality. We hope to receive equilibrium of interests. It is not the same as market equilibrium; rather equilibrium of interest means game or Nash equilibrium. So, similar to the specification of interest functions for participants (farmers and eco-food users), we need to specify the objective function of eco-management. In our set-up power is generated through cooperation between contracting eco-food-users (money) and the ecosystem (BD, nature). We may think of a syndicate (as consortium) specifying terms of financial contribution and BD provision. In political economy modeling [20] the social benefit (function) is amended by impacts from lobbying. In the given case, a lobby can be expressed equivalently as $\mathrm{g}^{\mathrm{k}}\left(\mathrm{c}^{\mathrm{k}}, \mathrm{d}^{\mathrm{k}}\right)$ and this is a lobbying function of company " $\mathrm{k}$ " and $\mathrm{g}^{\mathrm{f}}\left(\mathrm{c}^{\mathrm{f}}, \mathrm{d}^{\mathrm{f}}\right)$ is the lobbying function of the farm " $\mathrm{f}$ " sector

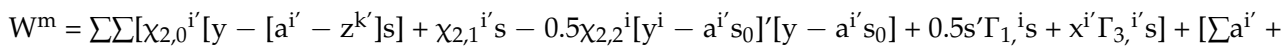

$$
\begin{aligned}
& \left.\mathrm{z}^{\mathrm{k}^{\prime}}\right] \mathrm{s}-\phi^{\mathrm{f}} 0^{\prime} \mathrm{s}-0.5 \mathrm{~s}^{\prime} \Xi_{1^{\prime}} \mathrm{s}+\mathrm{s}^{\prime} \Xi_{2}{ }^{\mathrm{f}}-\alpha 1 / \mathrm{n}\left[\sum \mathrm{a}^{\mathrm{i}}-1 / \mathrm{n} \sum \mathrm{a}^{\mathrm{i}}\right]^{\prime}\left[\sum \mathrm{a}^{\mathrm{i}}-1 / \mathrm{n} \sum \mathrm{a}^{\mathrm{i}}\right]+\sum \mathrm{g}^{\mathrm{k}}\left(\mathrm{c}^{\mathrm{k}}, \mathrm{d}^{\mathrm{k}}\right)+\mathrm{g}^{\mathrm{f}}\left(\mathrm{c}^{\mathrm{f}}, \mathrm{d}^{\mathrm{f}}\right)
\end{aligned}
$$

They lobby with the eco-management. The manager appreciates the new set-up of finance (6) because it can negotiate. The outcome is a compromise with companies in a syndicate and there is power and support. It means money works in creating interest. Money is used in compensation to stimulate farmers in order to receive a wished " $\mathrm{s}$ ". The provision is a balance of a power-oriented supply and demand (marginal revenue from eco-food users as income element for a company, see below on distribution effects), and we again assume that the marginal utility of income is equal to all citizens $\chi_{2,0}^{\mathrm{i}}=\chi_{2,0}$

$$
\mathrm{s}=\left[\Gamma_{1}{ }^{\mathrm{i}}+\Xi_{1}\right]^{-1}\left[\sum \chi_{2,1}{ }^{\mathrm{i}}+\chi_{2,0} \sum \mathrm{a}^{\mathrm{i}}+\Gamma_{3}{ }^{\mathrm{i}} \sum \mathrm{x}^{\mathrm{i}}+\sum \mathrm{a}^{\mathrm{i}}-\phi_{0}^{\mathrm{f}}+\Xi_{2}{ }^{\mathrm{f}} \mathrm{r}\right]
$$

By inserting this condition, we recognize vertical summation of preferences (job done by the eco-food-company) and marginal revenues as "market clearing" simulation which guarantees interest from the eco-food company. Finally, we receive (as reference) an interest function of eco-management based on $\sum \mathrm{a}^{\mathrm{i}^{\prime}}+\mathrm{a}^{\mathrm{m}^{\prime}}-\mathrm{z}^{\mathrm{k}}$. That function presents interest of a partial manager

$$
\begin{aligned}
& \mathrm{I}^{\mathrm{m}}=\mathrm{R}\left[\mathrm{x}^{\mathrm{i}^{\prime}} \Phi^{\mathrm{m}, \mathrm{i}, \mathrm{o}^{\prime}}\left[\sum \mathrm{a}^{\mathrm{i}}+\mathrm{a}^{\mathrm{m}^{*}}-\mathrm{z}^{\mathrm{k}^{\prime}}\right]+\left[\sum \mathrm{a}^{\mathrm{i}^{\prime}}+\mathrm{a}^{\mathrm{m}^{\prime}}-\mathrm{z}^{\mathrm{i}^{\prime}}\right] \Phi^{\mathrm{m}, \mathrm{i}, 1}\left[\sum \mathrm{a}^{\mathrm{i}}+\mathrm{a}^{\mathrm{m}^{*}}-\mathrm{z}^{\mathrm{k}^{\prime}}\right]\right]+\mathrm{x}^{\mathrm{f}^{\prime}} \Phi^{\mathrm{m}, \mathrm{f}, \mathrm{o}^{\prime}}\left[\sum \mathrm{a}^{\mathrm{i}^{\prime}}+\mathrm{a}^{\mathrm{m}^{* \prime}}\right]+\left[\sum \mathrm{a}^{\mathrm{i}^{\prime}}+\mathrm{a}^{\mathrm{m}^{* \prime}}\right]^{\prime} \\
& \Phi^{\mathrm{m}, \mathrm{f}, 1}\left[\sum \mathrm{a}^{\mathrm{i}^{\prime}}-\mathrm{z}^{\mathrm{k}^{\prime}}+\mathrm{a}^{\mathrm{m}^{* \prime}}\right]-\alpha 1 / \mathrm{n}\left[\sum \mathrm{a}^{\mathrm{i}}-1 / \mathrm{n} \sum \mathrm{a}^{\mathrm{i}}\right]^{\prime}\left[\sum \mathrm{a}^{\mathrm{i}}-1 / \mathrm{n} \sum \mathrm{a}^{\mathrm{i}}\right]+\sum \mathrm{s}^{\mathrm{k}}\left(\mathrm{c}^{\mathrm{k}}, \mathrm{d}^{\mathrm{k}}\right)+\mathrm{s}^{\mathrm{f}}\left(\mathrm{c}^{\left.\mathrm{f}, \mathrm{d}^{\mathrm{f}}\right)}\right.
\end{aligned}
$$

In this specification of an interest function for the public nature management, payments are coming from eco-food-users by a willingness to pay for " $\mathrm{z}$ " (royalty). The company is a transmitter of beneficiary preferences in a mode of (collective) decision making. Companies delegate the preferences via money assigned to management. Management is the intermediary provider of the regional product to consumer having own interest. The syndicate vice versa is served by farmers with BD. Foods contain products processed under prestigious, regional product branding having nature as backing higher prices. The farm sector is the final provider, the eco-food company is the money collector and management is the coordinator. For all of them, an interest must prevail

$$
\begin{aligned}
& \mathrm{I}^{\mathrm{i}}=\mathrm{x}^{\mathrm{i}^{\prime}} \Phi^{\mathrm{i}, \mathrm{o}^{\prime}}\left[\mathrm{a}^{\mathrm{i}}-\mathrm{z}^{\mathrm{k}} / \mathrm{n}+\sum \mathrm{a}^{\mathrm{j}}-\mathrm{z}^{\mathrm{k}} / \mathrm{n}+\mathrm{a}^{\mathrm{m}^{*}}\right]+0.5\left[\mathrm{a}^{\mathrm{i}}-\mathrm{z}^{\mathrm{k}} / \mathrm{n}+\sum \mathrm{a}^{\mathrm{j}}-\mathrm{z} / \mathrm{n} \ldots+\mathrm{a}^{\mathrm{m}^{* \prime}}\right] \Phi^{\mathrm{i}, 1}\left[\mathrm{a}^{\mathrm{i}}-\mathrm{z}^{\mathrm{k}^{\prime}} / \mathrm{n}+\sum \mathrm{a}^{\mathrm{j}}\right. \\
& \left.-z \ldots+a^{m^{*}}\right]+\left[a^{i}-z^{k} / n\right]^{\prime} \Phi^{i, 2^{\prime}}\left[\sum a^{j}-z^{k} / n+a^{m^{*}}\right]+0.5\left[a^{i}-z^{k} / n\right]^{\prime} \Phi^{i, 3^{\prime}}\left[a^{i} / n-z^{k}\right]-c^{i}
\end{aligned}
$$

The internal inclusion of companies and management as intermediary (syndicate) in a consortium which can get the form of a syndicate allows us to formulate bargaining processes on the basis of individual interests in extraction $z^{\mathrm{k}}$ and it enables the specification of the $\mathrm{s}^{\mathrm{m}}$. This vector is still enabled by the money allocated to the eco-management. Yet it is a biased choice of " $\mathrm{s}$ ". 
Then, we need to understand the interaction of the value generating company with the management in the chain. Figure 2 shows the biased vertical integration of the WTP providing companies that represent the consumers. The eco-food-buyers are passive and the companies express their wills. In principle their willingness to pay is taken over by the company on behalf of the negotiated " $\mathrm{s}$ ". Above social welfare, the pure physical aspect of " $\mathrm{s}$ " appearance for direct use value, such as taste and preference for "s", matters. Finally, the approach is embedded in regional products which are promoted by indirect values containing BD. Given different elasticities of demand, we can presume that a company maximizes its returns minus costs like a monopsony; so, they know how much money they can render. This clarifies on procurement and distribution willingness shown to the eco-management. In general, the interest function of consumer and company are exchangeable on the basis of income and that extraction is maximized by the company.

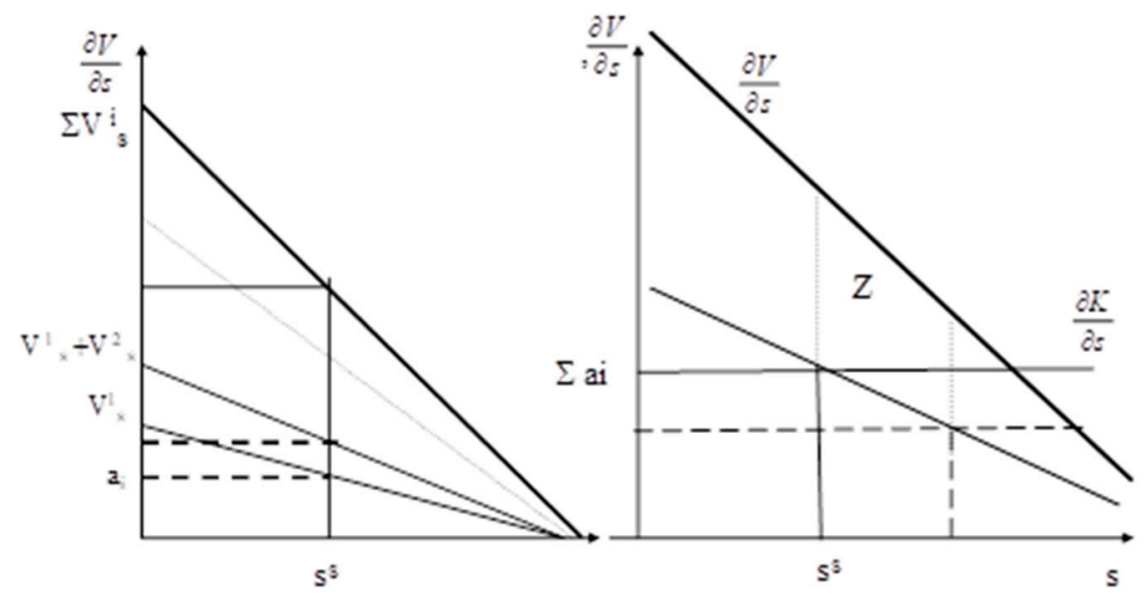

Figure 2. Eco-food-company preference aggregation and decision on margins for collecting finance.

Figure 2 shows two cost situations $\left(\sum \mathrm{a}^{\mathrm{i}}\right)$ : left high costs and right low costs. Optimal positions using joint public WTP as summation are given by the intersection with the aggregated demand. The further assumption is that any product is represented by one company only; this enables a segregated treatment and tells us the individual and social optimum.

In the Figure 2 the aggregation is vertical in the left picture. In the right picture we added the costs, in that case being linear because it is the payment per unit of " $\mathrm{s}$ " and this is a fix rate. Note that the distribution of financial returns can be curbed by companies negotiating with eco-management; both gain, but differently. From a company's perspective $\mathbf{a}^{\mathbf{i}}$ are costs which can be shifted in bargaining with eco-management which results in different returns to be calculated.

\subsection{Bargaining Equilibrium}

In a final step we can adopt the frame of Harsanyi (1963) [42], Zusman (1976) [43], and Rausser et al. (2012) [41]. It serves in translating the above outline into an interest driven cooperation between value chain, farm and public management. In such frame, a multiple agent game can be exemplified as function $\mathrm{L}($.$) . The game links interested functions constructed as deviation of benefits from participation$ in a game minus the opportunity costs not to participate in the game. There are a partial manager and agents which are subject to the capability to enforce the rules decided in the game.

$$
\mathrm{L}=\left[\prod_{\mathrm{i}}\left(\mathrm{I}^{i}-\mathrm{I}_{0}^{i}\right)\right]\left(\mathrm{I}^{f}-\mathrm{I}_{0}^{f}\right)\left(\mathrm{I}^{m}-\mathrm{I}_{0}^{m}\right)
$$

Since the construction of interest functions as outlined above already corresponds to the framework of Rausser and Zusman (1992) [20], an interior solution, similar to their solution, can be derived. It is again a matter of simulations, known based on extended interest functions. The solution results in a weighted objective function. For instance, in the function of management, individual 
weights correspond to the power of pressure (groups). Note as Zusman (1976) [43] has shown, bargaining solutions are not the same as a policy preference function. Rather, weights reflect the analytic properties of both aspects: the production function aspect of political support and the resources devotion aspect as means for political bargaining.

However, the result of bargaining models give weight to companies representing eco-food-users $\mathrm{w}^{\mathrm{k}}$ and farmers $\mathrm{w}^{\mathrm{f}}$. This is important for understanding the potential of cooperation and finding individual regulations. Objective functions are to be interpreted as interest functions of a partial management. By logic of collective bargaining, it is the objective function of cooperation on the one side, and the objective functions of individual preference for " $s$ " on the other side. It is concurrent individual and supra-individual and reflects interaction of individuals' preferences.

$$
\begin{aligned}
& \mathrm{L}=\sum \mathrm{w}^{\mathrm{k}}\left[\mathrm{x}^{\mathrm{k}^{\prime}} \Phi^{\mathrm{k}, \mathrm{o}^{\prime}}\left[\sum \mathrm{a}^{\mathrm{i}}+\mathrm{a}^{\mathrm{m}}+\mathrm{z}^{\mathrm{k}}\right]+\left[\sum \mathrm{a}^{\mathrm{i}}+\mathrm{a}^{\mathrm{m}}+\mathrm{z}^{\mathrm{k}}\right]^{\prime} \Phi^{\mathrm{k}, 1^{\prime}}\left[\sum \mathrm{a}^{\mathrm{i}}+\mathrm{a}^{\mathrm{m}}+\mathrm{z}^{\mathrm{k}}\right]\right]+\mathrm{w}^{\mathrm{f}} \mathrm{x}^{\mathrm{f}^{\prime}} \Phi^{\mathrm{f}, \mathrm{o}^{\prime}}\left[\sum \mathrm{a}^{\mathrm{i}}+\mathrm{a}^{\mathrm{m}^{\prime}}\right]+ \\
& 0.5\left[\sum \mathrm{a}^{\mathrm{i}}+\mathrm{a}^{\mathrm{m}}\right]^{\prime} \Phi^{\mathrm{f}, 1}\left[\sum \mathrm{a}^{\mathrm{i}^{\prime}}+\mathrm{a}^{\mathrm{m}^{\prime}}\right]+\sum\left[\mathrm{x}^{\mathrm{k}^{\prime}} \Phi^{\mathrm{m}, \mathrm{i}, \mathrm{o}^{\prime}}\left[\sum \mathrm{a}^{\mathrm{i}}+\mathrm{a}^{\mathrm{m}}+\mathrm{z}^{\mathrm{k}}\right]+\left[\sum \mathrm{a}^{\mathrm{i}^{\prime}}+\mathrm{a}^{\mathrm{m}^{\prime}}\right]^{\prime} \Phi^{\mathrm{m}, \mathrm{i}, \mathrm{1}^{\prime}}\left[\sum \mathrm{a}^{\mathrm{i}^{\prime}}+\mathrm{a}^{\mathrm{m}^{\prime}}\right]\right]+ \\
& x^{f^{\prime}} \Phi^{m, f, o^{\prime}}\left[\sum a^{i^{\prime}}+a^{m^{\prime}}\right]+\left[\sum a^{i^{\prime}}+a^{m^{\prime}}\right]^{\prime} \Phi^{m, f, 1^{\prime}}\left[\sum a^{i^{\prime}}+a^{m^{\prime}}\right]-\alpha 1 / n\left[\sum a^{i}-1 / n \sum a^{i}\right]^{\prime}\left[\sum a^{i}-1 / n \sum a^{i}\right]
\end{aligned}
$$

with

$\mathrm{W}=$ weights for power

Optimizing Equation (14), $\mathrm{a}^{1}, \ldots, \mathrm{a}^{\mathrm{i}}, \ldots, \mathrm{a}^{\mathrm{n}}, \mathrm{z}^{\mathrm{k}}$, and $\mathrm{a}^{\mathrm{m}}$ give the political bargaining equilibrium:

$$
\begin{aligned}
& \left.\vartheta \mathrm{W} / \vartheta \mathrm{a}^{1}=\mathrm{w}^{1} \Phi^{1, \mathrm{o}}+\Phi^{\mathrm{m}, 1, \mathrm{o}}\right] \mathrm{x}^{1}-\mathrm{w}^{\mathrm{f}} \Phi^{\mathrm{m}, \mathrm{f}, \mathrm{o}} \mathrm{x}^{\mathrm{f}}+\left[\sum\left[\mathrm{w}^{\mathrm{i}} \Phi^{\mathrm{i}, 1}+\Phi^{\mathrm{m}, \mathrm{i}, 1}\right]+\mathrm{w}^{\mathrm{f} 1} \Phi^{\mathrm{f} 1}+\Phi^{\mathrm{m}, \mathrm{f}, 1}\right]\left[\sum \mathrm{a}^{\mathrm{i}}+\mathrm{a}^{\mathrm{m}}+\mathrm{z}^{\mathrm{k}}\right]+ \\
& {\left[w^{1} \Phi^{11}+\Phi^{\mathrm{f}, 1,1}+\mathrm{w}^{\mathrm{m}, 1,1^{1}} \Phi\right] \mathrm{a}^{1}-\alpha 1 / \mathrm{n}\left[\sum \mathrm{a}^{\mathrm{i}}+\mathrm{a}^{1}\right]=0} \\
& \vartheta \mathrm{W} / \vartheta \mathrm{a}^{\mathrm{n}}=\left[\mathrm{w}^{\mathrm{n}} \Phi^{\mathrm{n}, \mathrm{o}}+\Phi^{\mathrm{m}, \mathrm{n}, \mathrm{o}}\right] \mathrm{x}^{\mathrm{n}}-\mathrm{w}^{\mathrm{f}} \Phi^{\mathrm{m}, \mathrm{f}, \mathrm{o}} \mathrm{x}^{\mathrm{n}}+\left[\sum\left[\mathrm{w}^{\mathrm{i}} \Phi^{\mathrm{n}, 1}+\Phi^{\mathrm{m}, \mathrm{n}, 1}\right]+\mathrm{w}^{\mathrm{fl}} \Phi^{\mathrm{f} 1}+\Phi^{\mathrm{m}, \mathrm{f}, 1}\right]\left[\sum \mathrm{a}^{\mathrm{i}}+\mathrm{a}^{\mathrm{m}}+\right. \\
& \left.\mathrm{z}^{\mathrm{k}}\right]+\left[\mathrm{w}^{\mathrm{n}} \Phi^{\mathrm{n}, 1}+\Phi^{\mathrm{f}, \mathrm{n}, 1}+\mathrm{w}^{\mathrm{m}, \mathrm{n}, 1^{\prime}} \Phi\right] \mathrm{a}^{\mathrm{n}}-\alpha 1 / \mathrm{n}\left[\sum \mathrm{a}^{\mathrm{i}}+\mathrm{a}^{1}\right]=0 \\
& \vartheta \mathrm{W} / \vartheta \mathrm{z}^{\mathrm{k}}=\left[\mathrm{w}^{\mathrm{k}} \Phi^{\mathrm{n}, \mathrm{o}}+\Phi^{\mathrm{m}, \mathrm{n}, \mathrm{o}}\right] \mathrm{x}^{\mathrm{n}}-\mathrm{w}^{\mathrm{f}} \Phi^{\mathrm{m}, \mathrm{fo}, \mathrm{o}} \mathrm{x}^{\mathrm{n}}+\left[\sum\left[\mathrm{w}^{\mathrm{k}} \Phi^{\mathrm{n}, 1}+\Phi^{\mathrm{m}, \mathrm{n}, \mathrm{l}}\right]+\mathrm{w}^{\mathrm{fl} 1} \Phi^{\mathrm{f1} 1}+\Phi^{\mathrm{m}, \mathrm{f}, 1}\right]\left[\sum \mathrm{a}^{\mathrm{i}}+\mathrm{a}^{\mathrm{m}}+\mathrm{z}^{\mathrm{k}}\right]=0 \\
& \dddot{\vartheta} / \vartheta \mathrm{a}^{\mathrm{m}}=\sum\left[\mathrm{w}^{\mathrm{i}} \Phi^{\mathrm{i}, \mathrm{o}}+\Phi^{* i, o}\right] \mathrm{x}^{\mathrm{i}}-\mathrm{w}^{\mathrm{f}} \Phi^{\mathrm{f}, \mathrm{o}} \mathrm{x}^{\mathrm{f}}+\left[\sum\left[\mathrm{w}^{\mathrm{i}} \Phi^{\mathrm{i}, 1}+\Phi^{* \mathrm{i}, 1}\right]+\mathrm{w}^{\mathrm{f} 1} \Phi^{\mathrm{f1}}+\Phi^{\mathrm{f}^{\mathrm{f}}}\right]\left[\sum \mathrm{a}^{\mathrm{i}^{\prime}}+\mathrm{a}^{\mathrm{m}^{\prime}}+\mathrm{z}^{\mathrm{k}}\right]+ \\
& 2 \sum\left[w^{\mathrm{i}} \Phi^{\mathrm{i} 1}+\Phi^{\mathrm{i}^{*} 1}+w^{\mathrm{f} 11^{\prime}}+\Phi^{* \mathrm{f}}\right] \mathrm{a}^{\mathrm{m}}=0
\end{aligned}
$$

In fact in such given frame royalty " $\mathrm{z}$ " in Equation (14) can be specified further as the function embedded in:

$\mathrm{a}^{\mathrm{m}}=\sum \mathrm{p}^{r} z^{r^{\prime}} A+\mathrm{c}^{\mathrm{m}^{\prime}}$ and hence $\vartheta \mathrm{W} / \vartheta \mathrm{a}^{\mathrm{m}}=\ldots \mathrm{p}^{r^{\prime}} A_{1}{ }^{\prime}$ is the relevant optimization.

Reorganizing the equations structure in (14), we receive a new system of " $n, k+1$ " equations.

Figure 3 depicts the bargaining equilibrium and gives royalties as the outcome of the bargaining. In Figure 3, one can see the shift from social welfare equilibrium to a bargaining equilibrium as social and private marginal utility divert. Therefore, to say it is the "group" which decides, but because he has power, the eco-management holds the position of the master player which enforces regulation.

Technically for simulation, the solution of the bargaining model is a system of equations including weights and interest, which serves for final simulation. It simultaneously explains contributions of particular interest groups " $\mathrm{k}$ " to provision of the public good, $\mathrm{z}^{1}, \ldots, \mathrm{z}^{\mathrm{i}}, \ldots, \mathrm{z}^{\mathrm{m}}$. Also, it includes the level of subsidy $\mathrm{c}^{\mathrm{m}}$ and rent of companies as well as internally determines the level and feature of public good "s". For empirical application, since utility functions and profit as objectives can be specified by programming, there is scope for finding data and coefficients. The objective function of the management can be equally constructed [37], for example based on extended programming using targets in BD management. 


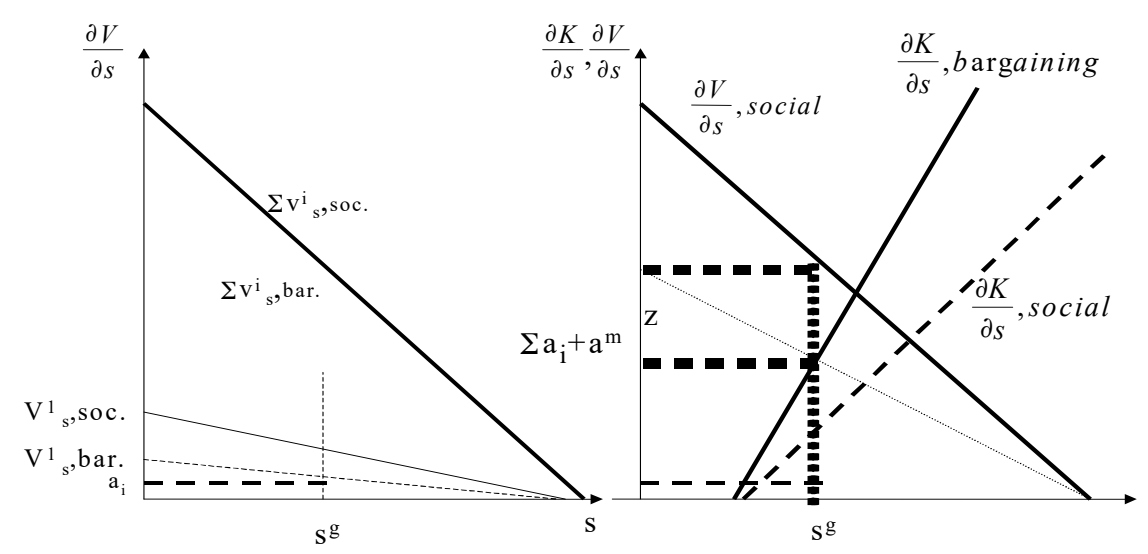

Figure 3. Aggregation of Social Welfare and Bargaining for Political Economy "Equilibrium".

\section{Summary and Outlook}

The presented type of analysis can be applied to situations in which, for example, groups of consumers as well as value chain-oriented companies and farmers have a special interest in the provision of BD. Presuming that they prefer eco-foods and there is a willingness to pay, the approach enables simulations on contractual arrangements. With financial contributions in value chains finance is generated. This finance goes to public management and public management of eco-systems which are embedded in landscapes and use the money to compensate farmers which accept BD provision. Public management delivers money to farmers on the basis of own interest as well by some coercion it guarantees participation in public good provision and avoids free riding [44]. By anticipating preferences, the management has authority to decide on a special type of nature preservation which follows authority to establish a preferred nature (multi-functionality in the eyes of farmers). Farmers' marginal cost functions for provision of $\mathrm{BD}$ can be evaluated using data from already existing schemes of nature provision. The management is informed on value added through cooperation with companies in the food chain. Gaining companies participate in a mode of nature conservation paying royalties. There should be trust in the companies' WTP on behalf of consumers and WTA of farmers to choose nature for receiving compensation. Charging of royalties for $\mathrm{BD}$, the management has financial power to assure provision of BD. However, this social coordination is not a "social optimum", since management is partial and does (under auspices of power) follow own objectives. Management has specific $\mathrm{BD}$ interest. This is in line with the thought that eco-management is done mostly by biologist pursuing an agenda. However, the management works together with eco-food sellers and farmers to optimize for a BD, which is notably a compromise. The paper showed how the compromise can be achieved through a simulation and necessary equations are elaborated.

The management of $\mathrm{BD}$, as public good raised in a landscape, has the power to charge royalties and in cooperation with any party management is better off pursuing its own interest. Such interest is specific as it strives for nature and not money. Apparently, power is necessary and it is created through missing alternatives to get eco-foods at conventional markets. Also, there is willingness to concede power to an agency, partly converting the public multi-functionality into a private commodity. A prerequisite is that companies in the food chain learn to financially support regional management in their own interest. It is suggested that an instrument for learning is the simulation of the cooperation which can be reached through bargaining. As has been highlighted, we have a complex system of dependency, though it guarantees provision of money and ESS simultaneously. If the compensation and reciprocal delivery of food includes $\mathrm{BD}$, conservation becomes a joint product. As shown, especially the political economy framework management can include power (and measures need power). It can result in BD becoming a subject of interest for all parties involved; but the result is partial. The wished $\mathrm{BD}$ of management and community driven interest in BD for sales, expressed as local providers of eco-foods, depends on money. Eco-food-preference functions can be derived from expenditure as well as WTP and respectively, land allocation is secondary. 
As conclusion drawn for recommendation to those who want to develop models for simulation, we think it is very important to show that there are ways to place the complex interaction of BD provision, payment for nature and value chain improvements into one concept. The delineation is that biodiversity ( $\mathrm{BD}$ as vector) has the scope to be valuable at marketing, ready for compensation at farm level and implementation, as well as being manageable for landscape design.

Funding: This research received no external funding.

Conflicts of Interest: The authors declare no conflict of interest.

\section{References}

1. Grossman, M.R. Multi-functionality and non-trade concerns. In Agriculture and International Trade: Law, Policy, and the WTO; Cardwell, M.N., Grossman, M.R., Rodgers, C.P., Eds.; CAB International: Oxon, UK, 2003.

2. Bergstrom, T.; Blume, L.; Varian, H. On the Private Provision of Public goods. J. Public Econ. 1986, 29, 25-49. [CrossRef]

3. Oskam, A.; Slangen, L. The Financial and Economic Consequences of a Wildlife Development and Conservation Plan: A case study for Ecological Mains Structure in the Netherlands. In The Economics of Landscape and Wildlife Conservation; Dabbert, S., Dubgaard, A., Slangen, L., Whithby, M., Eds.; CAB International: Wallingford, UK, 1998; pp. 113-134.

4. Sandmo, A. Public Goods. In A Dictionary in Economics; Eatwell, J., Milgate, M., Newman, P., Eds.; Palgrave Macmillan: London, UK, 1987; pp. 1061-1066.

5. Defrancesco, E.; Merlo, M. Landscapes Values in Farming and Forestry Environmental Accounting (Area Scale Versus Enterprise Approach). In The Economics of Landscape and Wildlife Conservation; Dabbert, S., Dubgaard, A., Slangen, L., Whithby, M., Eds.; CAB International: Wallingford, UK, 1998; pp. 135-158.

6. Williamson, O.E. Economic institutions: Spontaneous and intentional governance. J. Law Econ. Organ. 1991, 7, 159-187. [CrossRef]

7. Ghosh, M.; John, G. Strategic fit in industrial alliances: An empirical test of governance value analysis. J. Mark. Res. 2005, 63, 131-165. [CrossRef]

8. Marotta, G.; Nazzaro, C. Responsabilità Sociale e Creazione di Valore Nell'impresa Agroalimentare: Nuove Frontiere di Ricercar; Economia Agro-Alimentare, n.1; Franco Angeli: Milano, Italy, 2012.

9. Vatn, A. An institutional analysis of payments for environmental services. Ecol. Econ. 2010, 69, 1245-1252. [CrossRef]

10. Latacz-Lohmann, U. Mechanisms for the Provision of Public Goods in the Countryside. In The Economics of Landscape and Wildlife Conservation; Dabbert, S., Dubgaard, A., Slangen, L., Whithby, M., Eds.; CAB International: Wallingford, UK, 1998; pp. 173-186.

11. Watts, D.C.H.; Ilbery, B.; Maye, D. Making reconnections in agro-food geography: Alternative systems of food provision. Prog. Hum. Geogr. 2005, 29, 22-40. [CrossRef]

12. Merlo, M.; Milocco, E.; Virgilietti, P. Market Remuneration for Goods and Services Provided by Agricolture and Forestry. In CAP Regimes and the European Countrysides; Brouwer, F., Lowe, P., Eds.; CABI: Wallingford, UK, 2000.

13. Pretty, J.N. Regenerating Agriculture: Policies and Practices for Sustainability and Self-Reliance; Joseph Henry Press: London, UK, 1995.

14. Duelli, P. Biodiversity evaluation in agricultural landscapes: An approach at two different scales. Agric. Ecosyst. Environ. 1997, 62, 81-91. [CrossRef]

15. Jacobides, M.G.; Knudsen, T.; Augier, M. Benefiting from innovation: Value creation, value appropriation and the role of industry architectures. Res. Policy 2006, 35, 1200-1221. [CrossRef]

16. Gowdy, J.M. The value of biodiversity: Markets, society and eco-system. Land Econ. 1997, 73, 25-41. [CrossRef]

17. Menard, C.; Shirley, M.M. Handbook of New Institutional Economics; Springer: Cham, The Netherlands, 2005.

18. Hagedorn, K. Natural Resource Management: The role of cooperative institutions and governance. J. Entrep. Organ. Divers. 2013, 2, 101-121. [CrossRef]

19. Hanley, N.; Kirkpatrick, H.; Simpson, I.; Oglethorpe, D. Principles for the Provision of Public Goods from Agriculture: Moorland Conservation in Scotland. Land Econ. 1998, 74, 102-113. [CrossRef] 
20. Rausser, G.C.; Zusman, P. Public Policy and Constitutional Prescription. Am. J. Agric. Econ. 1992, 74, $247-257$. [CrossRef]

21. Clarke, E.H. Multipart Pricing of Public Goods. Public Choice 1971, 11, 17-33. [CrossRef]

22. Ebert, U. Evaluation of Non Market Goods: Recovering Unconditional Preference. Am. J. Agric. Econ. 1998, 80, 241-254. [CrossRef]

23. Cooke, B.; Moon, K. Aligning 'public good' environmental stewardship with the landscape-scale: Adapting MBIs for private land conservation policy. Ecol. Econ. 2015, 114, 152-158. [CrossRef]

24. Nazzaro, C.; Marotta, G.; Rivetti, F. Responsible Innovation in the Wine Sector: A Distinctive Value Strategy. Agric. Agric. Sci. Procedia 2016, 8, 509-551. [CrossRef]

25. Vatn, A.; Vedeld, P. Fit, interplay, and scale: A diagnosis. Ecol. Soc. 2012, 17, 12-23. [CrossRef]

26. Fisher, A.; Sandström, S.; Delibes-Mateos, M.; Arroyo, B.; Tadie, D.; Randall, D.; Hailu, F.; Lowassa, A.; Msuha, M.; Kereži, V.; et al. On the multifunctionality of hunting-An institutional analysis of eight cases from Europe and Africa. J. Environ. Plan. Manag. 2013, 56, 531-552. [CrossRef]

27. Mueller, D. Public Choice: A survey. J. Econ. Lit. 1976, 14, 395-433.

28. Mueller, D. Public Choice. In The Encyclopedia of Public Choice; Rowley, C.K., Schneider, F., Eds.; Springer: Boston, MA, USA, 2004; pp. 32-48.

29. Scherr, S.; Milder, J.C.; Shames, S. Paying for Biodiversity Conservation in Agricultural Landscapes. In Agriculture, Biodiversity and Markets; Lockie, S., Carpenter, D., Eds.; Earthscan: London, UK, 2010; pp. $229-252$.

30. Smith, V.K. Can Contingent Valuation Distinguish Economic Values for Different Public Goods. Land Econ. 1996, 72, 139-151. [CrossRef]

31. Wunder, S.; Engel, S.; Pagiola, S. Designing payments for environmental services in theory and practice: An overview of the issues. Ecol. Econ. 2008, 65, 663-674.

32. Phalan, B.; Onial, M.; Balmford, A.; Green, R.E. Reconciling Food Production and Biodiversity Conservation: Land Sharing and Land Sparing Compared. Science 2011, 333, 1289-1291. [CrossRef] [PubMed]

33. Bromley, D.W. Environmental governance as stochastic belief updating: Crafting rules to live by. Ecol. Soc. 2012, 17, 14. [CrossRef]

34. Rawlins, J.M.; de Lange, W.J.; Fraser, D.C.G. An Ecosystem Service Value Chain Analysis Framework: A Conceptual Paper. Ecol. Econ. 2018, 147, 84-95. [CrossRef]

35. Norton, D.; Reid, N. Nature and Farming: Sustaining Native Biodiversity in Agricultural Landscapes; Csiro Publishing: Collingwood, Australia, 2013.

36. Kasymov, U.; Zikos, D. Understanding Human Actions and Institutional Change: What Are the Impacts of Power Asymmetries on Efficiency in Pasture Use? Resources 2017, 6, 71. [CrossRef]

37. Nuppenau, E.-A. Integrated modelling of payment for ecosystem services: Using willingness to pay and accept, for nature provision and addressing public management in cultural landscape. Oper. Res. Int. J. 2014, 14, 151-175. [CrossRef]

38. De Groot, R.S.; Alkemade, R.; Braat, L.C.; Hein, L.; Willemen, L. Challenges in integrating the concept of ecosystem services and values in landscape planning, management and decision making. J. Ecol. Complex. 2010, 7, 260-272. [CrossRef]

39. Bowen, H. The Interpretation of Voting in the Allocation of Economic Resources. Q. J. Welfare Econ. 1943, 58, 27-48. [CrossRef]

40. Millerton, J.C. Theory of value with public goods: A Survey article. J. Econ. Theor. 1972, 5, 419-477. [CrossRef]

41. Rausser, G.; Swinnen, J.; Zusman, P. Political Power and Economic Policy Theory, Analysis, and Empirical Applications; Cambridge University Press: Cambridge, UK, 2012.

42. Harsanyi, J.C. A simplified bargaining model for the n-person cooperative game. Int. Econ. Rev. 1963, 4, 194-220. [CrossRef]

43. Zusman, P. The incorporation and measurement of social power in economic models. Int. Econ. Rev. 1976, 17, 447-462. [CrossRef]

44. Zikos, D.; Roggero, D. The Patronage of Thirst: Exploring Institutional Fit on a Divided Cyprus. Ecol. Soc. 2012, 18, 1-13. [CrossRef]

(C) 2018 by the author. Licensee MDPI, Basel, Switzerland. This article is an open access article distributed under the terms and conditions of the Creative Commons Attribution (CC BY) license (http://creativecommons.org/licenses/by/4.0/). 